\title{
HUBUNGAN PENGETAHUAN DENGAN SIKAP IBU TENTANG MAKANAN PENDAMPING ASI DI DESA KLUMPANG KAMPUNG
}

\author{
Fatwiany
}

STIKes Sehat, Medan, Indonesia

Email: Wie.ranaya@gmail.com

\begin{abstract}
Abstrak
Makanan Pendamping ASI merupakan makanan tambahan bagi bayi yang diberikan pada 6 bulan pertama setelah kelahiran bayi. Wordl Health Organization (2017) menyatakan bahwa lebih kurang $40 \%$ bayi yang mendapatkan Asi Saja sedangkan sekitar $60 \%$ bayi yang berusia dibawah dari 6 bulan sudah mendapatkan makanan pendamping asi. Riskesdas 2018 tercatatat lebih dari $15 \%$ bayi berusia kurang dari 6 bulan masih mendapat makanan tambahan. survei awal di Desa klumpang kampung didapatkan dari 10 ibu terdapat 6 ibu memberikan makanan selain ASI dini pada bayi. Penelitian ini bertujuan mengetahui hubungan pengetahuan dengan sikap ibu tentang pemberian makanan pendamping ASI di desa klumpang Kampung Penelitian ini merupakan penelitian analitik dengan desain cross sectional menggunakan uji Chi-Square dengan tingkat kepercayaan 95\%. Sampel yang digunakan berjumlah 38 orang dari Ibu Menyusui Di Desa Klumpang Kampung. Hasil analisis pengetahuan Pemberian Makanan Pendamping Asi sebanyak $63.2 \%$ dengan kategori baik, sedangkan sikap 50\% memiliki sikap positif dan 50\% negative. Hasil uji chi-square tentang Hubungan Pengetahuan dengan Sikap Ibu Menyusui diperoleh nilai $\mathrm{p}=0,007$ $(\mathrm{p}<0,05)$ maka terdapat hubungan yang bermakna antara pengetahuan dan sikap Ibu Menyusui dalam Pemberian Makanan Pendamping Asi Di Desa Klumpang Kampung. Disarankan tenaga Kesehatan pendidik Kesehatan dapat memberikan Pendidikan kesehatan terkait tentang Makanan pendamping ASI.
\end{abstract}

Kata Kunci : Pengetahuan,Sikap, Ibu Menyusui, Makanan Pendamping Asi

\begin{abstract}
Complementary foods are complementary foods for babies that are given in the first 6 months after the baby's birth. The World Health Organization (2017) states that approximately $40 \%$ of infants who receive breast milk only, while about $60 \%$ of infants under the age of 6 months have received complementary foods. Riskesdas 2018 recorded that more than 15\% of infants aged less than 6 months still received additional food. The initial survey in Klumpang Village found that from 10 mothers there were 6 mothers providing food other than early breastfeeding for babies. This study aims to determine the relationship between knowledge and mother's attitude regarding complementary feeding in Klumpang Village. This research is an analytic study with a cross sectional design using the Chi-Square test with a 95\% confidence level. The samples used were 38 people from breastfeeding mothers in the village of Klumpang Kampung. The results of the analysis of knowledge on the provision of complementary feeding as much as $63.2 \%$ in the good category, while the attitude of 50\% has a positive attitude and 50\% is negative. The results of the chi-square test on the relationship between knowledge and attitudes of breastfeeding mothers obtained a value of $p=0.007$ ( $p<0.05$ ), so there was a significant relationship between
\end{abstract}


knowledge and attitudes of breastfeeding mothers in the provision of complementary feeding in Klumpang Kampung Village. It is recommended that health educators can provide health education related to complementary foods for breastfeeding.

Keywords $\quad$ : Knowledge, Attitude, Breastfeeding Mothers, Complementary Foods

\section{Pendahuluan}

Pandangan dari sebagian masyarakat terhadap bayi yang rewel adalah karena belum kenyang, ASI ibu encer sehingga bayi diberikan MP ASI, padahal makanan yang paling baik untuk bayi dalam 6 bulan pertama setelah kelahiran adalah air susu ibu (ASI), bayi berumur 6 bulan keatas dapat diperkenalkan dengan ragam makanan padat walaupun sampai anak berusia dua tahun tetap diberikan ASi oleh ibu. Pemberian makanan tambahan selain ASI akan lebih baik jika ibu membrikan dengan baik, maka memerlukan pengetahuan dan perilaku yang baik pula mengenai MPASI. Pengetahuan merupakan salah satu factor intern yang mempengaruhi terbentuknya perilaku manusia (Notoatmodjo, 2014).

MP-ASI merupakan makanan tambahan bagi bayi. Pemberian makanan tambahan ASI dengan usia bayi kurang dari empat bulan akan mengalami terjadi resiko gizi kurang lima kali lebih besar daripada bayi yang diberikan makanan selain ASI pada umur enam bulan. Pemberian makanan tambahan selain ASI yang terlalu cepat akan berpengaruh pada pertambahan berat badan bayi (Utami, 2015). Pemberian MP ASI sebelum berusia 6 bulan memiliki resiko gangguan kesehatan yaitu diare, anemia, resiko infeksi meningkat, obesitas, dan alergi terhadap zat gizi yang terdapat dalam makanan. Dampak negative dari pemberian makanan pendamping ASI yang terlambat juga menimbulkan serangkaian gangguan pada kesehatan seperti kekurangan nutrisi dan kemampuan oromotorik (gangguan sistem gerakan otot yang menyeluruh dalam mulut) kurang terstimulasi. (Istianty,A. dan Rusilanti,2014 ; Kemenkes, 2010).

Pengetahuan adalah hasil dari tahu dan ini terjadi setelah orang melakukan penginderaan terhadap objek tertentu. Waktu dalam pemberian MP ASI di antaranya meliputi kapan saat anak diberi MP ASI dan kemampuan menyediakan MP ASI yang bergizi. Sikap merupakan reaksi atau respon yang masih tertutup dari seseorang terhadap suatu stimul atau objek. Data yang diperoleh di Indonesia pada tahun 2016 prevalensi ibu menyusui yang memberikan MP-ASI adalah 64,61\%, kemudian pada tahun 2014 hanya sekitar 41,40\% dan pada tahun 2015 semakin menurun hingga 30,14\% ibu yang memberikan MP-ASI secara dini (Utami (2015). Data yang diperoleh dari dinas Kesehatan Kota Medan diperoleh bahwa cakupan pemberian MP-ASI di Kota Medan tahun 2018 mencapai 60,3\% namun yang memberikan MP-ASI sesuai dengan usia pemberian bayi hanya mencapai $20,1 \%$, dan semakin menurun pada tahun 2017 mencapai 12.2\% (Dinas Kesehatan Kota Medan, 2018). 
Survei pendahuluan di Desa Klumpang Kampung terhadap 10 ibu bayi 6-12 bulan, $40 \%$ orang ibu memberikan MP ASI tepat waktu dan $60 \%$ orang ibu memberikan MP ASI dini. Dan dari 10 ibu bayi 70\% tidak mengetahui bahwa bayi sampai usia $60 \%$ bulan hanya diberi ASI saja. Data tersebut menunjukkan banyak ibu yang memberikan MP ASI secara dini. Berdasarkan latar belakang di atas maka, penelitian tertarik untuk mengidentifikasi lebih jauh tentang 'Hubungan Pengetahuan dengan Sikap Ibu Menyusui Tentang Pemberian Makanan Pendamping Asi Di Desa Klumpang"

\section{Metode Penelitian}

Jenis penelitian ini analitik dengan rancangan penelitian yang di gunakan disini adalah cross sectional. Sampel peneliti ini adalah seluruh Ibu Menyusui tentang Pemberian Makanan Pendamping Asi yang bertempat tinggal di Desa Klumpang Kampung dengan jumlah 38 orang.

\section{Hasil Dan Pembahasan}

\section{Analisis Univariat}

Analisis Univariat dilakukan untuk melihat gambaran atau deskripsi suatu variabel penelitian yang disajikan dalam distribusi frekuensi dan persentase pada penelitian ini yaitu sebagai berikut:

Tabel 1. Distribusi Frekuensi berdasarkan Pengetahuan dan sikap Ibu Tentang Pemberian Makanan Pendamping Asi Di Desa Klumpang Kampung

\begin{tabular}{lcl}
\hline Pengetahuan & Frekuensi & \% \\
\hline Baik & 24 & 63,2 \\
Kurang & 14 & 36,8 \\
\hline Total & $\mathbf{3 8}$ & $\mathbf{1 0 0 , 0 0}$ \\
\hline & & \\
\hline Sikap & & \\
\hline Positif & 19 & 50,0 \\
\hline Negatif & 19 & 50,0 \\
\hline
\end{tabular}

Tabel di atas memperlihatkan pengetahuan Ibu Menyusui Sebagian besar memiliki pengetahuan dengan kategori baik sebanyak 24 responden $(63,2 \%)$ dan sedangkan 
pengetahuan dengan kategori kurang sebanyak 14 responden (36,8\%). Ibu memiliki sikap positif sebanyak 19 responden (50\%) dan sikap negatif juga sebanyak 19 responden $(50 \%)$.

\section{Analisis Bivariat}

Pengujian ststistik bivariat analisis menggunakan uji chi-square. Analisis ini dikatakan bermakna (signifikan).

Tabel 2 Distribusi Frekuensi berdasarakan Pengetahuan dengan Sikap Ibu Tentang Pemberian Makanan Pendamping Asi Di Desa Klumpang Kampung

\begin{tabular}{|c|c|c|c|c|c|c|c|}
\hline \multirow[t]{3}{*}{ Pengetahuan } & \multicolumn{4}{|c|}{ Sikap } & \multirow{2}{*}{\multicolumn{2}{|c|}{ Jumlah }} & \\
\hline & \multicolumn{2}{|c|}{ Positif } & \multicolumn{2}{|l|}{ Negatif } & & & \\
\hline & $\mathbf{N}$ & $\%$ & $\mathbf{N}$ & $\%$ & $\mathbf{N}$ & $\%$ & \\
\hline Baik & 16 & 66,7 & 8 & 33,3 & 24 & 100,00 & $\rho$ \\
\hline Kurang & 3 & 21,4 & 11 & 78,6 & 14 & 100,00 & 0,007 \\
\hline Jumlah & 19 & 50,0 & 19 & 50,0 & 38 & 100,00 & \\
\hline
\end{tabular}

Tabel diatas menunjukan data dari 24 responden yang memiliki pengetahuan baik sebanyak 16 responden $(66,7 \%)$ memiliki sikap positif tentang Pemberian Makanan Pendamping Asi sedangkan sebanyak 8 responden $(33,3 \%)$ memiliki sikap negatif. Dari 14 responden yang memiliki pengetahuan kurang sebanyak 11 responden $(78,6 \%)$ memiliki sikap negatif tentang Pemberian Makanan Pendamping Asi dan sebanyak 3 (21,4\%) memiliki sikap positif tentang Pemberian Makanan Pendamping Asi. Hasil uji statistic menggunakan chisqaure memperoleh nilai $\rho=0,007$ dimana $\rho<0,05$ dapat diartikan bahwa terdapat hubungan yang signifikan antara pengetahuan dan sikap Ibu Tentang Pemberian Makanan Pendamping Asi Di Desa Klumpang Kampung.

\section{Pembahasan}

Hasil uji statistik dengan menggunakan uji chi square menunjukkan nilai $\rho=0,007$ ( $\rho$ value $<0,05$ ), ada hubungan yang bermakna antara pengetahuan dengan sikap ibu tentang Pemberian Makanan Pendamping Asi di Desa Klumpang Kampung. Pengetahuan adalah salah satu dari ketiga komponen pembentuk sikap yaitu komponen kognitif. pengetahuan dan sikap berafiliasi secara konsisten. Jika komponen kognitif berubah, maka akan terjadi perubahan sikap. Berdasarkan teori (Sariyati, 2008). Secara nyata sikap menunjukkan adanya kesesuaian reaksi terhadap stimulus tertentu yang dalam kehidupan 
sehari- hari merupakan reaksi yang bersifat emosional terhadap stimulus sosial. Sikap adalah kesediaan untuk bertindak, dan bukan merupakan pelaksanaan motif tertentu (Notoatmodjo, 2014).

Sejalan dengan penelitian yang dilakukan oleh Siregar (2020) yang menyatakan bahwa terdapat hubungan pengetahuan dengan sikap ibu tentang pemberian makanan pendamping ASI (MP-ASI) di puskesmas Binjai estate. Menurut peneliti jika responden yang memiliki pengetahuan yang baik maka sikap Ibu tentang Pemberian Makanan Pendamping Asi juga memiliki sikap yang positif.

Pengetahuan yang baik dengan sikap yang positif merupakan hal yang sangat berhubungan dikarenakan jika responden memiliki pengetahuan yang baik maka ia mengerti bagaimana harus bersikap yang positif tentang Pemberian Makanan Pendamping Asi. Ibu memiliki pengetahuan yang baik yaitu responden yang mengerti apa itu makanan pendamping asi. Hal ini didapat dari pertanyaan yang diajukan peneliti didalam kuisioner dan presentase jawaban kuisioner memenuhi kriteria. Pengetahuan dikatakan kurang yaitu responden yang kurang mengerti apa itu makanan pendamping asi.

Ketidaktahuan ibu atau keluarga dalam memberikan makanan tambahan pada bayi dana adanya kebiasaan di lingkungan memberikan kerugian kesehatan baik secara langsung maupun tidak langsung pada bayi. Ibu bekerja mengalami situasi sulit untuk menyusui bayinya, dan memberikan PASI atau susu formula sebagai salah satu alternative meskipun ASI tetap diberikan. Agar bayi tidak merasa lapar dan menangis ibu dan keluarga memberikan makanan pada bulan pertama kelahiran, seperti pisang yang dikerok dan dihaluskan, nasi saring, bubur tepung, campuran nasi pisang dan sebagainya yang identik dengan Makanan Pendamping ASI (MP ASI). Sebagian besar jumlah ASI yang diperoleh berguna untuk pertumbuhan dan perkembangan bayi, termasuk energi dan zat gizi lainnya yang terkandung di dalam ASI tersebut. Hanya ASI tanpa bahan makanan lain sudah dapat mencukupi kebutuhan pertumbuhan usia sekitar enam bulan. ASI saja tanpa makanan pendamping disebut dengan ASI eksklusif. Pemberian ASI eksklusif selama 6 bulan pertama merupakan cara yang paling penting dalam pemberian makan pada bayi. Setelah bayi berusia lebih atau sama dengan 6 bulan, maka bayi membutuhkan lebih banyak zat besi dan seng daripada kandungan yang dapat ASI berikan, untuk tambahan nutrisi tersebut dapat diperoleh dari makanan padat.

\section{Kesimpulan}

Kesimpulan yang dapat kita peroleh dari penelitian ini bahwa dari 38 orang ibu menyusui memiliki pengetahuan baik sebesar 24 responden $(63,2 \%)$ dan memiliki sikap positif dan 19responden (50\%) memiliki sikap negatif dengan hasil uji statistik dengan menggunakan uji chi square menunjukkan nilai $\rho=0,007$ ( $\rho$ value $<0,05$ ), ada hubungan yang bermakna antara pengetahuan dengan sikap ibu tentang Pemberian Makanan Pendamping Asi di Desa Klumpang Kampung. 


\section{MIRACLE JOURNAL}

https://ojs.unhaj.ac.id/index.php/mj

\section{Referensi}

Arikunto. (2006). Prosedur Penelitian Suatu Pendekatan Praktik. Jakarta

Istianty.A.dan Rusilanti. (2014). Gizi Terapan. Bandung: PT REMAJA ROSDAKARYA

Dinkes Medan. (2018). Profil Kesehatan Sumatera Utara, Medan: Dinkes

Notoatmodjo. (2014) Ilmu perilaku kesehatan. Rineka Cipta. Jakarta

SDKI. 2018. Survei Demografi Dan Kesehatan Indonesia Tahun 2012.

Siregar, Ilham, S. (2020). Hubungan Pengetahuan dengan sikap ibu tentang pemberian makanan pendamping ASI (MP-ASI) di wilayah Puskesmas Binjai estate 2020. 5(2). $8-16$

Sugiyono. (2018). Metodologi Penelitian Pendidikan Kuantitatif, Kualitatif, R\&D. Jakarta: Alfabeta.

Sugiyono, 2015, Statistik Untuk Penelitian. Bandung, Alfabeta

Utami.2014. Buku Pintar MP-ASI Makanan Penunjang ASI 6 Bulan 15Tahun.Jakarta:arena KIDS.

WHO. 2018. Infant And Young Child Feeding. Diaksses dari http://www.who.int/mediacentre/factsheets/fs342/en/ 